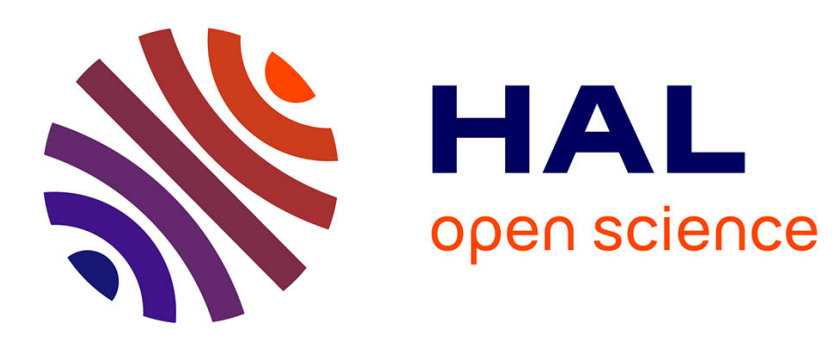

\title{
Acoustic documentation of 12 pipe organs and analysis of their plena
}

J. Stepánek, Z. Otcenásek

\section{To cite this version:}

J. Stepánek, Z. Otcenásek. Acoustic documentation of 12 pipe organs and analysis of their plena. Journal de Physique IV Proceedings, 1994, 04 (C5), pp.C5-645-C5-648. 10.1051/jp4:19945139 jpa00252816

\section{HAL Id: jpa-00252816 https://hal.science/jpa-00252816}

Submitted on 1 Jan 1994

HAL is a multi-disciplinary open access archive for the deposit and dissemination of scientific research documents, whether they are published or not. The documents may come from teaching and research institutions in France or abroad, or from public or private research centers.
L'archive ouverte pluridisciplinaire HAL, est destinée au dépôt et à la diffusion de documents scientifiques de niveau recherche, publiés ou non, émanant des établissements d'enseignement et de recherche français ou étrangers, des laboratoires publics ou privés. 


\title{
Acoustic documentation of 12 pipe organs and analysis of their plena
}

\author{
J. ŠTĚPÁNEK and Z. OTČENÁŠEK
}

VUZORT a.s., Plzenšká 66, Praha 5, 151 24, Czech Republic

\begin{abstract}
The method for acoustic measurement and documentation of pipe organs developed in 1991 in VUZORT, Prague enables to describe the sound of all organ pipes and plena measured in situ. The real time measurement and digitalisation of the sampled sound, computation and processing of the amplitude spectrum are possible without necessity of sound recording. Sampling frequencies were adjusted to the stop length and fundamental frequency of the measured tone. The results of factor analysis of the octave spectra of Great organ plenum for 12 instruments are described. The czech Baroque organs created a distinctive group in 3-dimensional factor space due to their rich harmonic spectra.
\end{abstract}

\section{INTRODUCTION}

There is a large number of pipe organs in the czech Republic. Many rare historical instruments from the Baroque period have kept their original specification of stops. The sound documentation is important to rescue the original sound character of old instruments. In 1991 and 1992 we have developed the method for acoustic measurements of organs aimed at documentation of the sound of historical instruments.

\section{DOCUMENTATION METHOD}

The acoustic documentation of organs according to our method [1] involves several types of measurement. The in situ measurement has been chosen for the organ sound documentation, thus the influence of the room acoustics is fully involved. The measurement equipment is based on a personal computer, completed with a DAP board involving a signal processor. The real time measurement and digitalisation are possible without necessity of sound recording. The base of the sound documentation is the measurement of the quasi-stationary part of the tones for all stops (registers) and plena. Following Lottermoser's ideas concerning organ plenum measurements [2] the triads of neighbouring semitones sounding in the same time are measured. Acoustic pressure levels are picked up by three microphones placed in the typical listening position in a church. A mean amplitude spectrum calculated in the real time as well as the time signal of the first microphone are saved. The accuracy of measurement with three microphones is discussed in [1].

For the measurement of steady-state parts of tones we have defined the sliding sample rate which is not only adapted to the stop foot length, but changes fluently following the fundamental frequency of each triad. The spectrum contains the same number of partial tones for all triads. The sliding sample rate enables a well arranged graphical representation of results (see Fig. 1 concerning the Mundt organ in the church of our Lady before Tyn, Prague). 


\section{ANALYSIS OF THE PLENUM SOUND}

\subsection{Analysed data}

The list of the instruments documented with vUzORT method is shown in the Table I. The instruments 1 to 8 represent a group of Baroque organs with original pipes and specification. The Baroque instruments 9 and 10 have been substantially reconstructed in 1992, the new instrument in Most (11) and the instrument 12 are new designed organs in which contemporary scaling and voicing principles were applied. We have chosen the plenum spectra of Great organ to evaluate the organ sound because the plena reflect both the builder's design ideas and the room influence in the large extent. The composition of stops of the investigated plena is shown in the Table II.

The keyboard compass of Baroque instruments is mostly from $c$ to c3. Using our way of the measurement of the stationary tone part, we have got 16 triads, which describe the sound in the octaves $c, c, c 1$ and $\mathrm{c2}$. Sound pressure levels calculated in five octave-bands (see Table III) were the input data for the analysis.

\subsection{Factor analysis of 12 Great organ plena}

We used the factor analysis model (FA) [3] for the statistical processing of the spectral data. FA is a mathematical method, through which a larger number of variables describing various object properties is substituted by the smaller number of new variables - factors. We used the principal component method and varimax rotation.

We applied the FA model on the levels calculated in five octavebands for each of sixteen tonal triads in twelve investigated plena as well as on the averages of spectral levels of four subsequent triads belonging to the same octave. Thus, each instrument was represented by four "absolute" spectra. The averaging of the level values through four octaves mentioned above make possible to represent each instrument by a "relative" spectrum, expressed by means of five level values. These spectra were also processed by means of FA. The results have been found similar in all three cases and have led to a three-factor solution. The explained variance was $97.7 \%$ in the last case. All these results are in a good agreement with the results of an earlier work made by Plomp [4]. The connection of the "relative" octave-bands with the factor loadings and the percentage of the explained variance are shown in the Table IV.

\subsection{Discussion}

The first factor depends both on the amplitude of the higher harmonics and the frequency extent of the plenum spectrum. The second factor is determined by the middle part of spectrum. The third factor depends, above all, on the first harmonic of the plenum, $i . e$. of the open Diapason. The obtained factor space of the investigated plena is shown in the Fig.2. The first factor coordinate was positive in Baroque instruments (except of the small organ on the side gallery in the st. Nicholas church, which had an extremely weak sound) and negative in four "modern" instruments. Consequently we can say that the Great organ plena of the czech Baroque organs had richer harmonic spectra then the modern instruments. This conclusion agrees well with the results of Plomp [4] who compared South and North German Baroque organs with modern instruments.

\section{CONCLUSIONS}

The used FA model has proved; that the results of the documentation measurement method which was described above constitute a good base for the future organ sound research. The possible comparison of "ideal" Baroque organ sound, typical for different regions or builders, with the sound of modern instruments could provide a common space of organ plena, in which the position of individual styles could be observed. 


\section{REFERENCES}

[1] Štěpánek J., Otčenášek Z., Syrový V., "Acoustic Documentation of Church Organs", SMAC 93, Stockholm 27-31 July 1993 (sent to press).

[2] Lottermoser W., Meyer J., Orgelakustik in Einzeldarstellungen, Teil I (Verlag Das Musikinstrument, Frankfurt am Main, 1966).

[3] Harman H.H., Modern factor analysis (The University of Chicago Press, London, 1967).

[4] Plomp R., Acustica 55 (1984) 193-194.

Table I. List of documented organs and plena under research.

$\begin{aligned} & \text { Place } \\ 1 & \text { Praha } \\ 2 & \text { Čský Krumlov } \\ 3 & \text { Praha } \\ 4 & \text { Polná } \\ 5 & \text { Ždár n. Sáz. } \\ 6 & \text { Dub na Moravè } \\ 7 & \text { Żlutice } \\ 8 & \text { Praha } \\ 9 & \text { Most/small organ } \\ 10 & \text { Most/main organ } \\ 11 & \text { Most/new organ } \\ 12 & \text { Praha }\end{aligned}$

Church / Hall
P.Marie pred Týnem
U P.Marie
sv. František
Nanebevzeti P. Marie
Nanebevzeti P. Marie
proboštsky chrám
sv. Petr a Pavel
sv.Mikulás
Gothic (transferred)
Gothic (transferred)
Gothic (transferred)
Rudolfinum

H.H.Mundt

N. Christeindel

A.Starck

J.D.Sieber

J.D.Sieber

J. Výmola

F.P.Noli

T. Schwarz

V.Starck

V.starck

Rieger-Kloss

Rieger-Kloss code

TYN

KRU

FRA

POL

ZDA

DUB

ZLU

MIK

MMO

VMO

BMO

RUD

Table II. Composition of Great organ plena.

Plenum code

open Diapason 8 '

Coppel Flute $8^{\prime}$

octave 4 '

Twelfth $22 / 3^{\prime}$

Fifteenth 2 '

Flute 2 '

Nineteenth $11 / 3^{\prime}+$ Twenty-second 1 ' + Mixture $2^{\prime}$

Mixture 1 1/3'

Mixture 1 ,

cimbel $2 / 3$ '
TYN KRU FRA POL ZDA DUB

$$
\begin{array}{ll}
+ & + \\
+ & + \\
+ & + \\
+ & + \\
+ & + \\
+ &
\end{array}
$$

$+$

VI IV

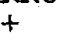

$+\quad+$

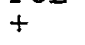

Table III. Octave-bands (frequencies in $\mathrm{Hz}$ ).

$\begin{array}{lr}\text { Tone } \backslash \text { oct: } & 1 \\ \mathrm{c}-\mathrm{H} & 64-128 \\ \mathrm{c}=\mathrm{h} & 128-256 \\ \mathrm{c} 1=\mathrm{h} 1 & 256-512 \\ \mathrm{c} 2-\mathrm{h} 2 & 512-1024\end{array}$

2
$128-256$
$256-512$
$512-1024$
$1024-2048$

4
$512-1024$
$1024-2048$
$2048-4096$
$4096-8192$

5
$1024-2048$
$2048-4096$
$4096-8192$
$8192-16384$

\begin{tabular}{|c|c|c|c|}
\hline $\begin{array}{c}\text { octave } \\
\text { band }\end{array}$ & fl & $\begin{array}{c}\text { Eactor } \\
\text { f } 2\end{array}$ & f3 \\
\hline $\begin{array}{l}1 \\
2 \\
3 \\
4 \\
5\end{array}$ & $\begin{array}{l}0.70 \\
0.78 \\
0.92\end{array}$ & $\begin{array}{l}0.79 \\
0.61 \\
0.55\end{array}$ & $\begin{array}{l}0.90 \\
0.51\end{array}$ \\
\hline$\%$ of variance & 42.6 & 28.8 & 26.3 \\
\hline
\end{tabular}

Table IV. Factor loadings for the "relative" octave-bands. 


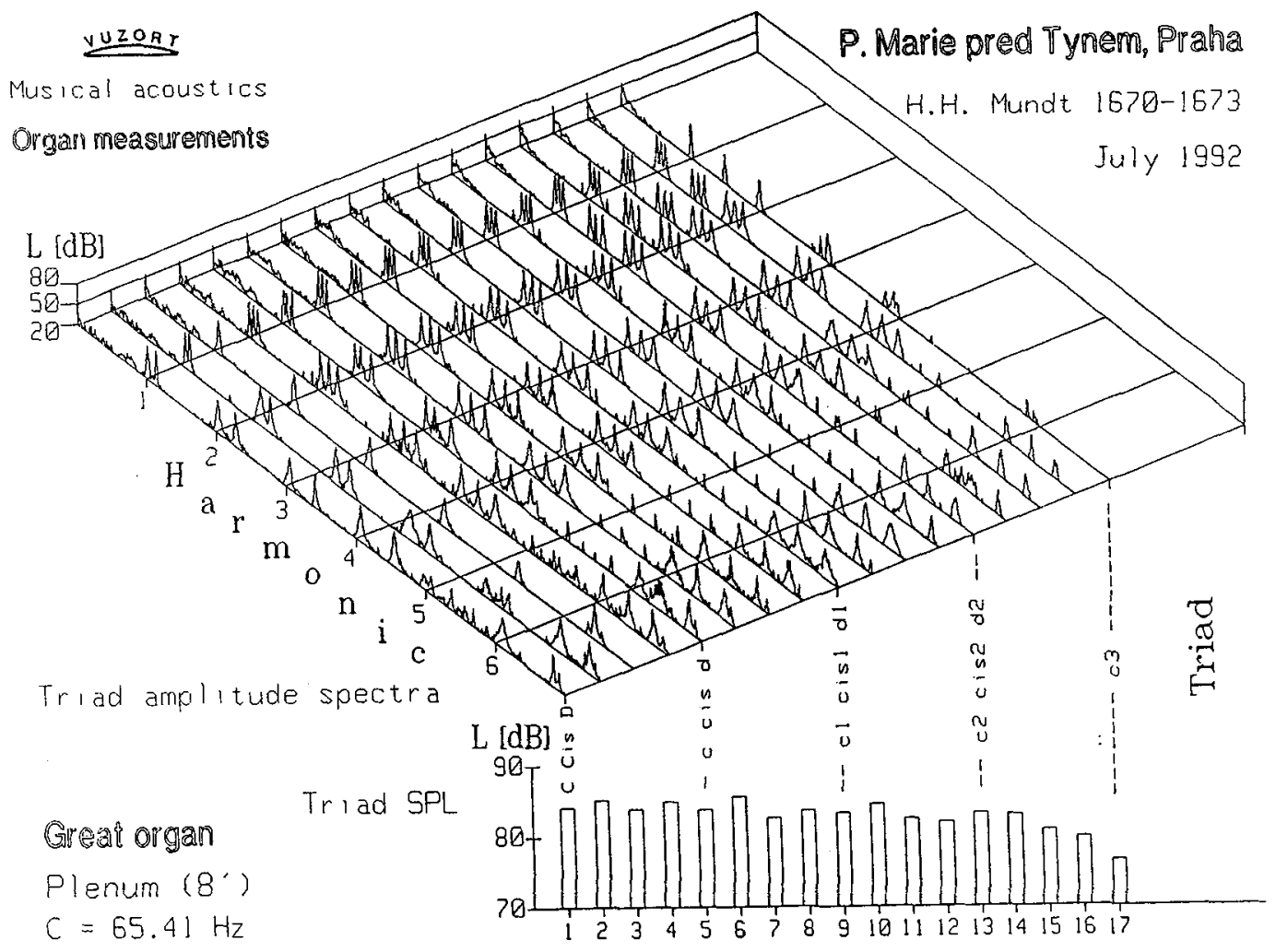

Fig.1. Graphical representation of an organ plenum sound documentation.

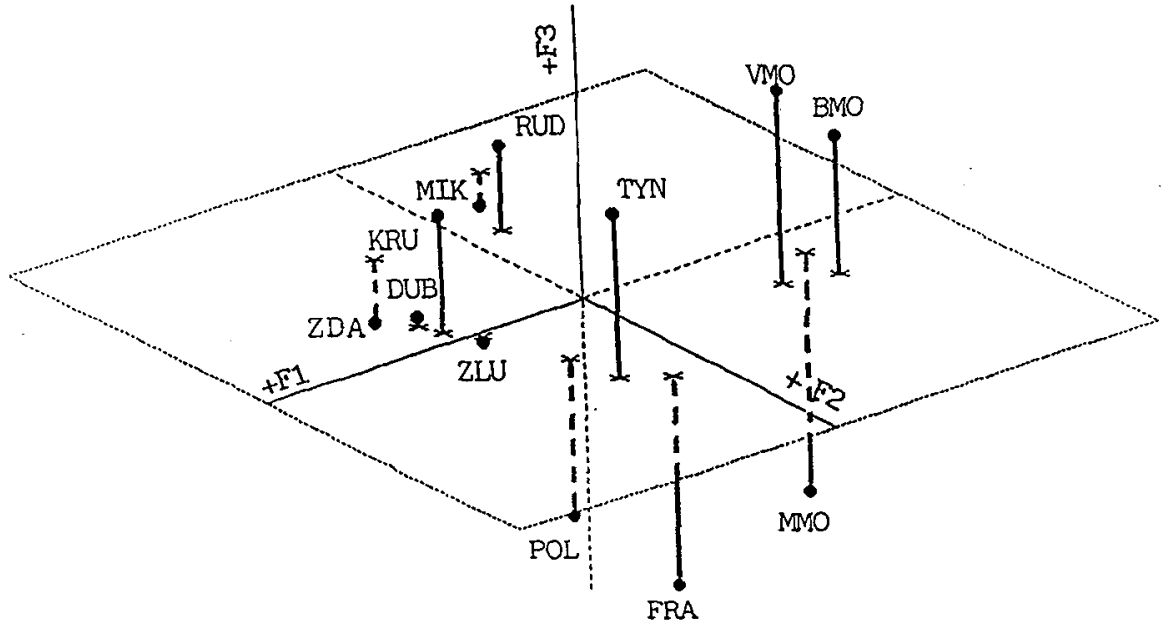

Fig.2. Resulting factor space of the analysed plena. 